Madrygal. Revista de Estudios Gallegos

ISSN: 1138-9664

\title{
Adeus a Victoria Álvarez Ruiz de Ojeda
}

\section{Luz Pozo Garza}

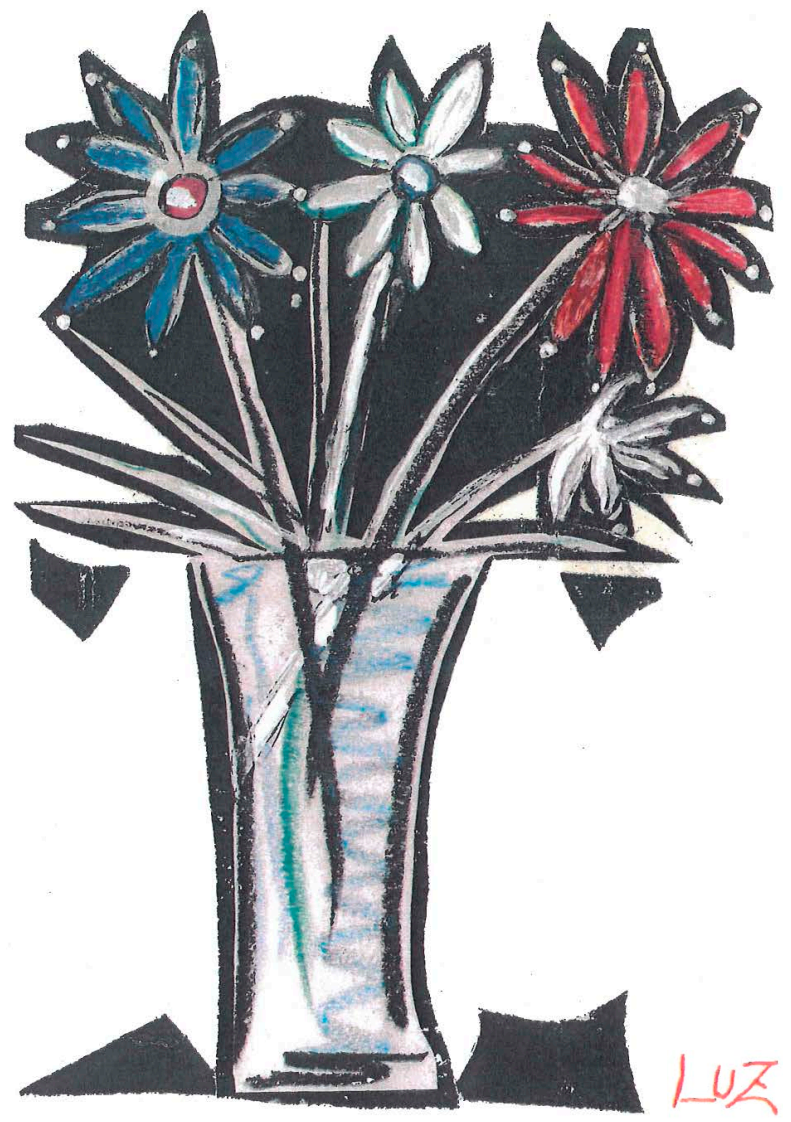

Filla de Rosalía.

Filla da túa naiciña

esposa de Xesús. Alonso. Montero

Adeus...

Que a identidade túa

sexa o espello dos máis. LU
Victoria tan querida:

Quixera que te acougues onde está Rosalía

Que lle achegues as flores que agora deseñei

Que compartades verbas e salmos e lembranzas

e a paixón polas fontes e a paixón polos ríos e a obstinación do mar e as camelias fechadas para despois da morte

e a fábula tan fráxil de ámbalas dúas vidas... inda sen madurar.

Adeus. Adeus. Victoria. Chéganvos reiseñores das rexións obstinadas...

amorosos diluvios de beizóns e de bágoas fican no corazón.

Sempre en Galicia.

Sempre

Nunca te olvidaremos no unánime silencio que nos deixa sen voz... 
LXesis:
Estur semprento..

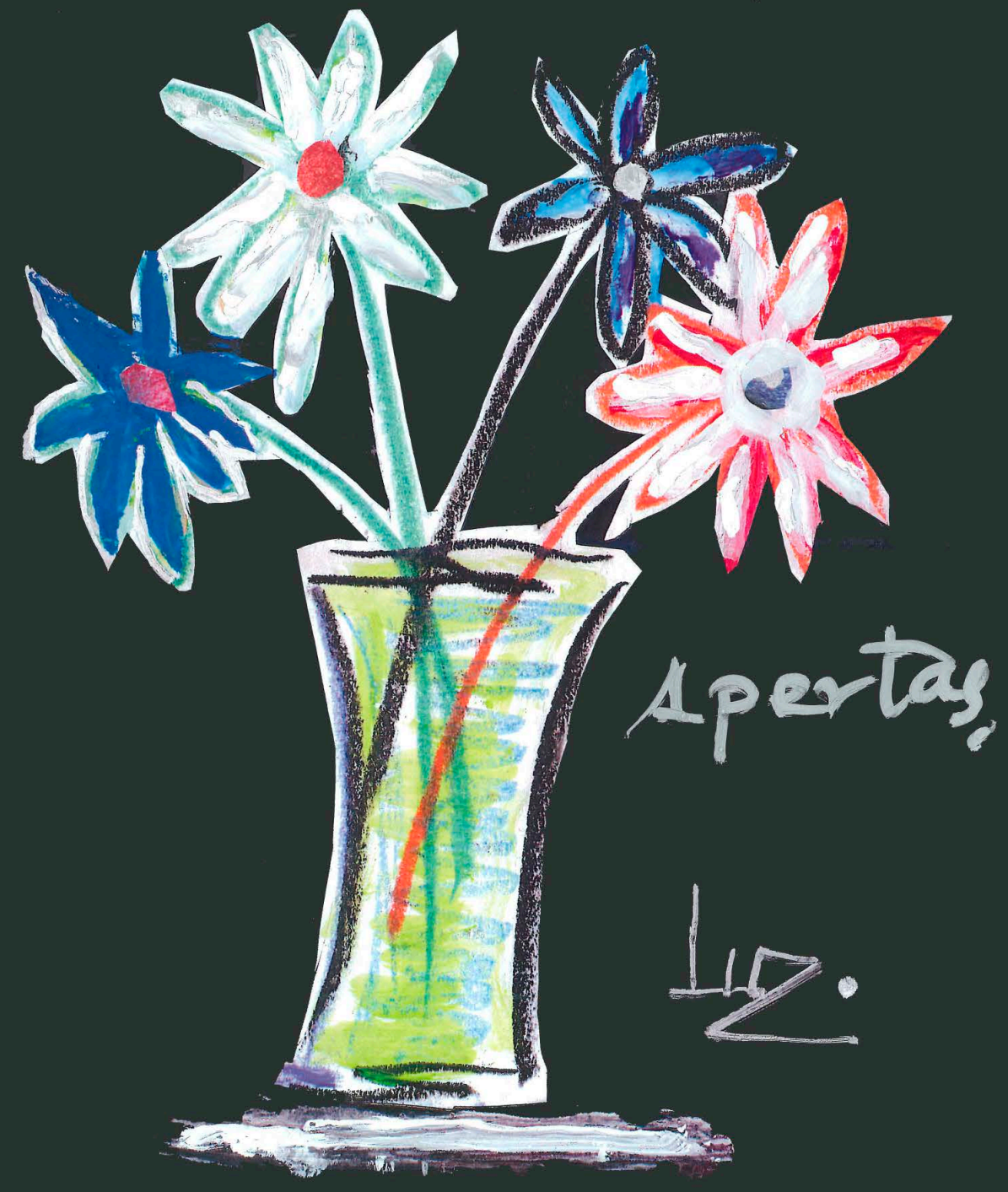

